\title{
Bath Additive Dosage Form
}

National Cancer Institute

\section{Source}

National Cancer Institute. Bath Additive Dosage Form. NCI Thesaurus. Code C149351.

A pharmaceutical dose form that is added to a bath. 